SAINS TANAH - Journal of Soil Science and Agroclimatology

Journal homepage: http://jurnal.uns.ac.id/tanah

\title{
The decomposition and efficiency of NPK-enriched biochar addition on Ultisols with soybean
}

\author{
Sugeng Winarso ${ }^{1 *}$, Marga Mandala ${ }^{1}$, Hari Sulistiyowati ${ }^{2}$, Sukron Romadhona ${ }^{1}$, Bambang Hermiyanto ${ }^{1}$, Wachju \\ Subchan ${ }^{3}$ \\ ${ }^{1}$ Faculty of Agriculture, Jember University, Jember, East Java, Indonesia \\ ${ }^{2}$ Faculty of Mathematics and Natural Science, Jember University, Jember, East Java, Indonesia \\ ${ }^{3}$ Faculty of Teacher Training and Education, Jember University, Jember, East Java, Indonesia
}

\begin{tabular}{|c|c|}
\hline ARTICLE INFO & ABSTRACT \\
\hline $\begin{array}{l}\text { Keywords: } \\
\text { Biochar } \\
\text { Decomposition } \\
\text { Efficiency } \\
\text { NPK } \\
\text { Ultisols } \\
\text { Article history } \\
\text { Submitted: 2019-12-04 } \\
\text { Accepted: 2020-06-29 } \\
\text { * Corresponding Author } \\
\text { Email address: } \\
\text { winarsosugeng@unej.ac.id }\end{array}$ & $\begin{array}{l}\text { This research aims to compare fresh biochar and NPK-enriched biochar and their } \\
\text { decomposition levels and nutrient absorption efficiency in acid soil with soybean. Factorial } \\
\text { randomized block design was used in this experiment and consisted of two factors. The } \\
\text { first factor, biochar source, comprised four levels: B0: biochar without NPK, B1: rice straw } \\
\text { biochar + NPK, B2: soybean straw biochar + NPK, and B3: wood biochar + NPK. The second } \\
\text { factor, biochar enrichment, comprised four levels: D1: } 0.5 \text { tons ha }{ }^{-1}, \mathrm{D} 2: 2.5 \text { tons ha }{ }^{-1}, \mathrm{D} 3 \text { : } \\
5.0 \text { tons ha }{ }^{-1} \text {, and D4: } 10 \text { tons ha }{ }^{-1} \text {. Each treatment was replicated three times, yielding } 48 \\
\text { experiment units. The results showed that biochar enrichment with NPK affected the } \\
\text { decomposition level. The percentage of increasing decomposition in enriched wood } \\
\text { biochar }(0.09 \%) \text { was lower than rice }(0.28 \%) \text { and soybean }(0.53 \%) \text { straw biochar. An } \\
\text { increase in NPK absorbance efficiency and soybean dry weight was evident in NPK-enriched } \\
\text { biochar. The highest N absorbance efficiency occurred in wood biochar ( } 21 \%) \text {, followed by } \\
\text { soybean and rice straw biochar, respectively, while the highest P and K absorbances were } \\
\text { found in rice straw biochar ( } 35 \% \text { and } 26 \% \text {, respectively), followed by wood and then } \\
\text { soybean biochar. }\end{array}$ \\
\hline
\end{tabular}

How to Cite: Winarso, S., Mandala, M., Sulistiyowati, H., Romadhona, S., Hermiyanto, B., and Subchan, W. (2020). The decomposition and efficiency of NPK-enriched biochar addition on Ultisols with soybean. Sains Tanah Journal of Soil Science and Agroclimatology, 17(1): 35-41 (doi: 10.20961/stjssa.v17i1.37608)

\section{Introduction}

One of the efforts made to cope with the gradual decrease of soil fertility and productivity, particularly due to the decreased level of soil organic matter (Sanderman, Creamer, Baisden, Farrell, \& Fallon, 2017), is the application of biochar. Biochar denotes a chemically stable source of $C$, which means the $C$ remains intact in the soil for hundreds and even thousands of years (Lehmann, 2007; Lehmann \& Joseph, 2009). Organic matter from biochar can last 10 to 1000 times longer than soil organic matter (Verheijen, Jeffery, Bastos, van der Velde, \& Diafas, 2010). These properties have sparked a great number of scientists' interest in studying it and using it as a method to increase soil fertility and health when tackling environmental issues, especially global warming (Schahczenski, 2010; Levine, 2010). Applying biochar in agricultural practices is also considered a sequestration (absorbing and storing) process for the $\mathrm{C}$ in the soil (Steinbeiss, Gleixner, \& Antonietti, 2009). Therefore, such farming practices are considered to be appropriate for sustainable farming. This massive potential of biochar to restore all kinds of natural resources, including soil, water, and air, has been exceedingly crucial, particularly for farming fields in tropical regions with high temperature and rainfall like Indonesia.

The process of biochar production, in which high temperatures in oxygen-lacking circumstances-commonly called pyrolysis-lead to nutrient deficiencies, especially of $\mathrm{N}$, P, and S (McLaughlin, Shields, Jagiello, \& Tiele, 2012; Winarso, Hermiyanto, Mandala, Sulistiyowati, \& Ilmiawan, 2017). Despite this, it also has advantageous functions, such as: having wide coverage, escalating soil cation exchange capacity (CEC) (Sohi, Lopez-Capel, Krull, \& Bol, 2009), improving water holding capacity (WHC), and other physical features (Herath et al., 2013; Abel et al., 2013). However, its influence on soil fertility and plant productivity varies 
exponentially over time (Mukherjee \& Zimmerman, 2013). Biochar was lack of nutrients, especially NPS, which, in contrast to its direct application in the field, obstructs plant growth due to the immobilization process. Furthermore, Bachmann et al. (2016) reported that the measurement results from 22 laboratories in 12 countries demonstrated that a wide range of biochar varieties indicated high levels of C, pH (SD <10\%), H, P, ash (SD 10-20\%), and other substances. Mukherjee and Zimmerman (2013) pointed out that biochar as a soil amendment is exceptionally promising because it can improve $C$ and soil fertility sequestration. However, its effects on soluble organic carbon (C-organic), N, and P in its cycle or decay have been under-researched.

Previous research has revealed that applying biochar in the agriculture field (Dariah \& Nurida, 2012; Winarso et al., 2017; Abel et al., 2013) generated significant response and high prospective for future development (McLaughlin, Anderson, Shields, \& Reed, 2009). In line with these studies, Schahczenski (2010), claimed that biochar was a potential generator of renewable-energy-based farming, highly sought after in tropical regions with high rates of weathering. Commonly, the rate of weathering on organic substances is higher than the rate of replenishment. Therefore, most farming areas experience a constant decrease in organic substances. Wang, Xiong, and Kuzyakov (2015) revealed that biochar will decrease or obstruct the decomposition of organic soil substances by small amounts of approximately $3.8 \%$, called negative priming. On the other hand, in sandy soil, it was found that biochar robustly triggers the mineralization of organic soil substances by $20.8 \%$ or stimulates microbe activity. Biochar can improve organic soil substances and extend $C$ sequestration in the soil (Yadav et al., 2017). Biochar can enhance water supply without creating resistance in soil (Herath et al., 2013). Zheng et al. (2013) added that biochar can improve corn growth and raise nitrogen utilization efficiency (NUE) on corn. Yet, it concomitantly decreases $\mathrm{N}$ accumulation efficiency (NAE). This indicates that biochar can increase the availability of $\mathrm{N}$ in the farming field. Moreover, it proves that biochar has great potential to decrease the need for $\mathrm{N}$ fertilizer for plants.

Several factors affect the acceleration of biochar decomposition in soil, including experiment duration, raw material, pyrolysis temperature, and clay load. Wang et al. (2015) have evaluated biochar stability through 128 observations of $\mathrm{CO}_{2}$ from biochar and 24 studies using $\mathrm{C}\left({ }^{13} \mathrm{C}\right.$, stable) and $\left({ }^{14} \mathrm{C}\right.$, radioactive), to demonstrate biochar decomposition in soil and to calculate and estimate mean residence time (MRT). The process or the amount of decomposed biochar initially increases logarithmically and decreases over time. The MRT of biochar's C existence, based on unstable pools and recalcitrant, is estimated to be 108 days and 556 years, with pool sizes of $3 \%$ and $97 \%$, respectively. Based on the background above, the purpose of the study is to compare fresh biochar and NPK-enriched biochar and their efficiency in acid soil with planted soybean.

\section{Materials and Method}

The study was conducted in August 2018 in the laboratory and greenhouse of the Faculty of Agriculture, University of Jember. The soil sample of Ultisols was taken from Bogor, West Java. Biochar was prepared using rice straw, soybean straw, and wood in the Soil Science Laboratory Agriculture Faculty. The biochar was treated to be enriched with NPK, derived from urea, SP36, and $\mathrm{KCl}$.

The characteristics of the biochar samples were determined (see Table 1). The C: $\mathrm{N}$ ratio of the wood was higher than that of the other kinds of biochar. This indicates that wood has a potential stable in the soil. Table 1 reveals that all the biochar contained small amounts of macronutrients (particularly $\mathrm{N}$ and $\mathrm{P}$ ), great numbers of base elements ( $\mathrm{K}, \mathrm{Ca}, \mathrm{Mg}$, and $\mathrm{Na})$, a high $\mathrm{C}: \mathrm{N}$ ratio, and a relatively high load of ash.

According to the analysis results concerning small amounts of NPK in the biochar, the research design of enriching the biochar with NPK by adding urea, SP36, and $\mathrm{KCl}$ to achieve appropriate levels and proportions of these elements confirms soybeans' need for it. Manshuri's (2012) research showed that soybean absorption encompassed 240 $\mathrm{N} \mathrm{kg} \mathrm{ha}{ }^{-1}, 102 \mathrm{P}_{2} \mathrm{O}_{5} \mathrm{~kg} \mathrm{ha}^{-1}$, and $120 \mathrm{~K}_{2} \mathrm{O} \mathrm{kg} \mathrm{ha}{ }^{-1}$. The amount of absorbed nutrients is design the requirement of NPK for biochar enrichment. The results of the calculations of this treatment are shown in Table 2. The NPK ratio is 8:5:4, which is used to test soybean on Ultisols.

The Ultisols used in this study was taken from Bogor, West Java, and has a low pH level. Based on the evaluation of soil fertility status using variables, the Ultisols shows low CEC, low base saturation (BS), a medium C-organic level, and a low amount of NP nutrient (Table 3). It indicates the Ultisols was categorized as infertile or possesses low soil fertility.

Based on the characteristics of the soil, the research was conducted to enrich biochar for profitable agricultural practices. The experiment was conducted through a completely randomized factorial design involving two factors: Factor I: NPK-enriched biochar (8:5:4) source comprising four variants:

B0: Biochar without NPK

B1: NPK-enriched rice straw biochar (8:5:4)

B2: NPK-enriched soybean straw biochar (8:5:4)

B3: NPK-enriched wood biochar (8:5:4)

Factor II: The concentration of biochar (ton ha-1), consisting of four levels:

D1: 0.5 tons ha $^{-1}$

D2: 2.5 tons $\mathrm{ha}^{-1}$

D3: 5.0 tons ha ${ }^{-1}$

D4: 10 tons ha ${ }^{-1}$

Each treatment was repeated three times, yielding 48 experiment units. The decomposition and efficiency of NPKenriched biochar, when added to Ultisols with soybean, was investigated using a two-factor design to increase soil properties. The analysis was carried out to evaluate the final total number of decomposition processes. This was measured by the C-organic ( $\mathrm{C}$ was oxidized with $\mathrm{Cr}$ and measured using a spectrophotometer), $\mathrm{pH}$ ( $\mathrm{pH}$-meter in 1:5 suspension), $\mathrm{N}, \mathrm{P}$, and $\mathrm{K}$ (concentrated $\mathrm{H}_{2} \mathrm{SO}_{4}$ extract and $\mathrm{H}_{2} \mathrm{O}_{2}$ ). The efficiency of NPK-enriched biochar addition to Ultisols was measured using the NPK absorption and the soybean dry weight. 
Table 1. The characteristics of biochar obtained from various sources

\begin{tabular}{lccc}
\hline Characteristics & Wood & $\begin{array}{c}\text { Rice } \\
\text { Straw }\end{array}$ & $\begin{array}{c}\text { Soybean } \\
\text { Straw }\end{array}$ \\
\hline $\mathrm{C} \mathrm{mg} \mathrm{kg}^{-1}$ & 941 & 541 & 258 \\
$\mathrm{~N} \mathrm{mg} \mathrm{kg}$ & & 0.8 & 1.3 \\
$\mathrm{P} \mathrm{mg} \mathrm{kg}$ & & 4 & 4 \\
$\mathrm{~K} \mathrm{mg} \mathrm{kg}^{-1}$ & 3 & 170 & 176 \\
$\mathrm{Ca} \mathrm{mg} \mathrm{kg}$ & 301 & 212 & 209 \\
$\mathrm{Mg} \mathrm{mg} \mathrm{kg}$ & 254 & 183 & 181 \\
$\mathrm{Na} \mathrm{mg} \mathrm{kg}$ & 70 & 7.01 & 7.30 \\
$\mathrm{C}: \mathrm{N}$ & 12.5 & 634 & 657 \\
$\mathrm{C}: \mathrm{P}$ & 704 & 159 & 164 \\
$\mathrm{pH}$ & 235 & 8.21 & 8.00 \\
$\mathrm{Ash} \%$ & 7.35 & 50.4 & 50.5 \\
\hline
\end{tabular}

Table 2. NPK designed for biochar enrichment (8:5:4) in variant addition doses in soil

\begin{tabular}{ccccc}
\hline Doses & $\begin{array}{c}\text { Biochar } \\
\left(\mathrm{kg} \mathrm{ha}^{-1}\right)\end{array}$ & $\begin{array}{c}\text { Urea } \\
\left(\mathrm{kg} \mathrm{ha}^{-1}\right)\end{array}$ & $\begin{array}{c}\text { SP36 } \\
\left(\mathrm{kg} \mathrm{ha}^{-1}\right)\end{array}$ & $\begin{array}{c}\mathbf{K C l} \\
\left(\mathrm{kg} \mathrm{ha}^{-1}\right)\end{array}$ \\
\hline 0.5 tons ha $^{-1}$ & 308.88 & 86.96 & 70.83 & 33.33 \\
2.5 tons ha $^{-1}$ & 1544.4 & 434.78 & 354.17 & 166.67 \\
tons ha $^{-1}$ & 3088.8 & 869.57 & 708.33 & 333.33 \\
10 tons ha $^{-1}$ & 6177.5 & 1739.1 & 1416.7 & 666.67 \\
\hline
\end{tabular}

Table 3. The characteristics of Ultisols from Bogor, West Java.

\begin{tabular}{lll}
\hline Variable & Unit & Ultisols \\
\hline $\mathrm{pH} \mathrm{H}_{2} \mathrm{O}(1: 5)$ & & 4.20 \\
$\mathrm{pH} \mathrm{KCl} \mathrm{(1:5)}$ & $\%$ & 4.35 \\
$\mathrm{C}$ & $\%$ & 1.81 \\
Organic matter & $\%$ & 3.15 \\
$\mathrm{~N}$ & & 0.20 \\
$\mathrm{C}: \mathrm{N}$ & $\mathrm{ppm}$ & 9.05 \\
$\mathrm{P}_{2} \mathrm{O}_{5}$ Bray-1 extract & $\mathrm{Cmol.kg-1}$ & 10 \\
$\mathrm{~K}_{2} \mathrm{O}(\mathrm{HCl}$ extract 5\%) & $\mathrm{Cmol.kg-1}$ & 23.40 \\
$\mathrm{CEC}(\mathrm{NH} 4-$-acetic acid $\mathrm{N} \mathrm{pH} \mathrm{7)}$ & $\%$ & 18 \\
$\mathrm{BS}$ & $\%$ & 65 \\
$\mathrm{Al}(\mathrm{CEC}$ ef) saturation & $\%$ & \\
\hline
\end{tabular}

\section{Results}

\subsection{Decomposition or biochar stability}

Figure 2 shows biochar addition from several sources and NPK-enriched treatment on Ultisols organic level (C-organic). The results show that biochar addition $(0.5 ; 2.5 ; 5.0$; and 10 tons $\mathrm{ha}^{-1}$ ) tends to increase soil C-organic (\%). Interestingly, the results show a similar dose had dissimilar biochar effects on soil C-organic, which indicates that wood biochar with no NPK enrichment (see blue marking in Figure 2) shows the highest amount of soil C-organic. The trend is similar in the other treatments (biochar + NPK), which tend to decrease, such as wood biochar + NPK, rice straw biochar + NPK, soybean straw biochar + NPK, respectively.

Figure 2 also indicates an increase in the biochar dose added to the Ultisols. There is a similar trend in the quadratic curve with specific variance according to the combined dose and NPK-enriched biochar. Similar results confirm the findings of de Figueredo, da Costa, Melo, Siebeneichlerd, and Tronto (2017). Biochar enrichment involving NPK (8:5:4) also led to different effects on soil C-organic. The different impacts on soil C-organic highlighted different rates of biochar decomposition: NPK-enriched biochar accelerated the decomposition rate or decreased the decomposition stability in soil. There is a difference in the equations for each enrichment.

On the other hand, this means that the percentage of $\mathrm{C}$ organic decreases due to an increase in NPK-enriched biochar decomposition compared to biochar with no enrichment. This is based on the biochar source, which evinces the lowest figure on wood-based biochar $(0.09 \%)$ compared to that on rice straw $(0.28 \%)$ and soybean $(0.53 \%)$. This is rational in as much as the richer the biochar (lower $\mathrm{C}: \mathrm{N}$ and $\mathrm{C}: \mathrm{P}$ ) was, the more triggered the microbiological activity driving decomposition would be. However, a correlation ( $r$ ) test involving soil C-organic with microbe density (total microbe), fungus density, and diminutive bacteria generated insignificantly invariant results: $0.05 ; 0.14$; and -0.02 , respectively.

Figure 3 shows the increases in biochar decomposition from various sources after NPK enrichment. This was calculated based on the difference evident between NPKenriched biochar (8:5:4) and basic biochar, which in the wood was below $0.1 \%$. However, it was 2.8 times higher with rice straw biochar $(0.28 \%)$, and over 5 times higher with soybean biochar (0.53\%). These results show that biochar enrichment with NPK improves the properties of soil fertility, and plant production indicates the impact of biochar's decomposition rate. This contrasts with Wang et al. (2015), who claimed that the decomposition resulted from unstable pools with very low levels (only $3 \%$ of the total level). Furthermore, Wang et al. (2015) described the MRT of biochar as 108 days, while the rest was the recalcitrant pool (97\%), the MRT of which was much longer: 556 years.

Figure 4 shows that biochar addition to Ultisols escalates soil $\mathrm{pH}$ according to the dose increase. The increase in Ultisols $\mathrm{pH}$, initially marked at 4.2 and reaching up to approximately 10 , produces 10 tons ha ${ }^{-1}$ of biochar addition. The Ultisols $\mathrm{pH}$ increases occurred due to base elements $(\mathrm{K}, \mathrm{Ca}, \mathrm{Mg}$, and $\mathrm{Na})$ which qualification of great biochar. For example, the wood biochar with a $\mathrm{pH}$ of 7.35 shows $301 \mathrm{mg} \mathrm{kg}^{-1}$ of $\mathrm{K}, 254 \mathrm{mg} \mathrm{kg}^{-1}$ of $\mathrm{Ca}, 70 \mathrm{mg} \mathrm{kg}^{-1}$ of $\mathrm{Mg}$, and $12.5 \mathrm{mg} \mathrm{kg}^{-1}$ of $\mathrm{Na}$. The complete data for the remaining biochar samples are shown in Table 1. Figure 4 shows the effect of biochar addition on the improvement of soil $\mathrm{pH}$, comparing biochar without NPK and biochar with NPK (8:5:4). The effects of biochar without NPK are higher than those of biochar with NPK (8:5:4). The data also indicate that the difference in $\mathrm{pH}$ of nearly 2 digits affects processes in the soil, such as decomposition, dissolution, nutrient availability, and microbe activity. 

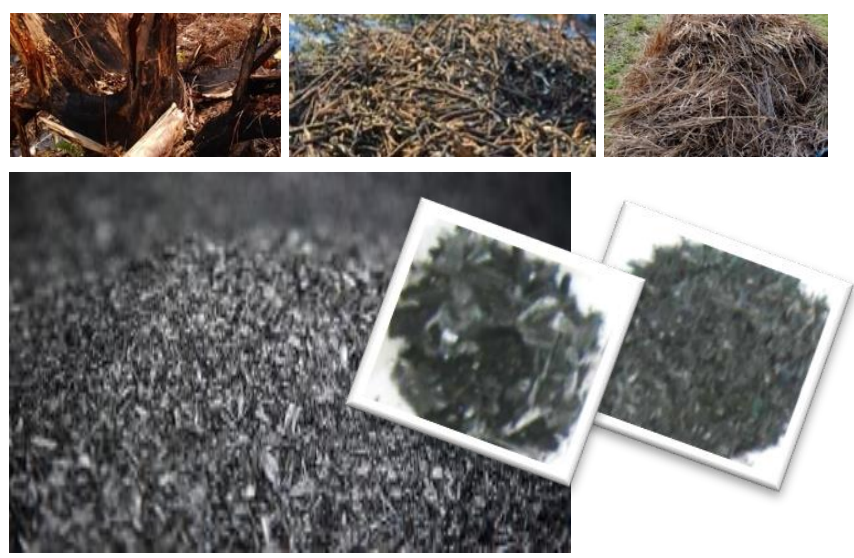

Figure 1. Biochar from several sources employed in the research

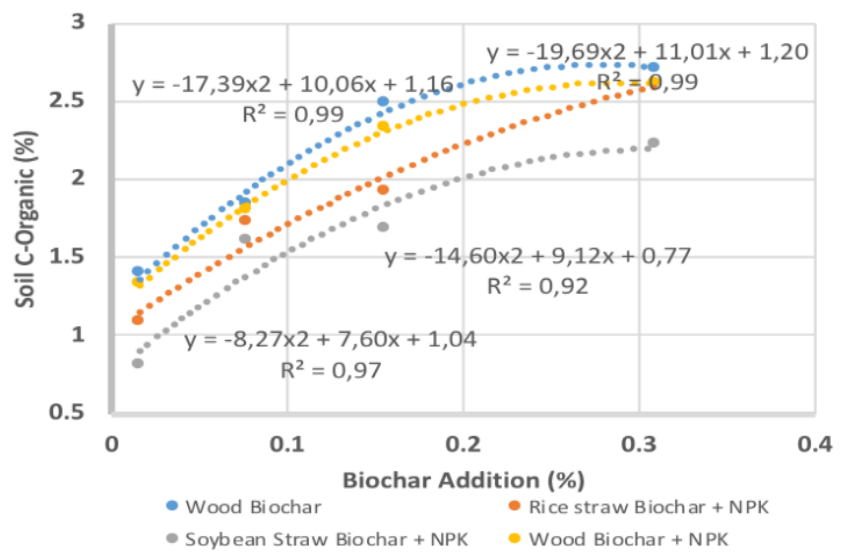

Figure 2. Soil C-organic level based on biochar addition from various sources

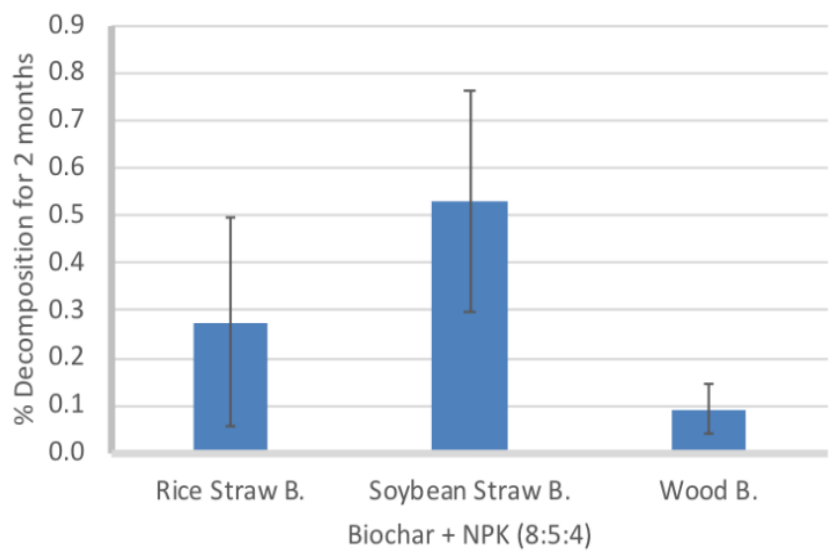

Figure 3. The rate of increase of biochar decomposition in various sources after NPK enrichment

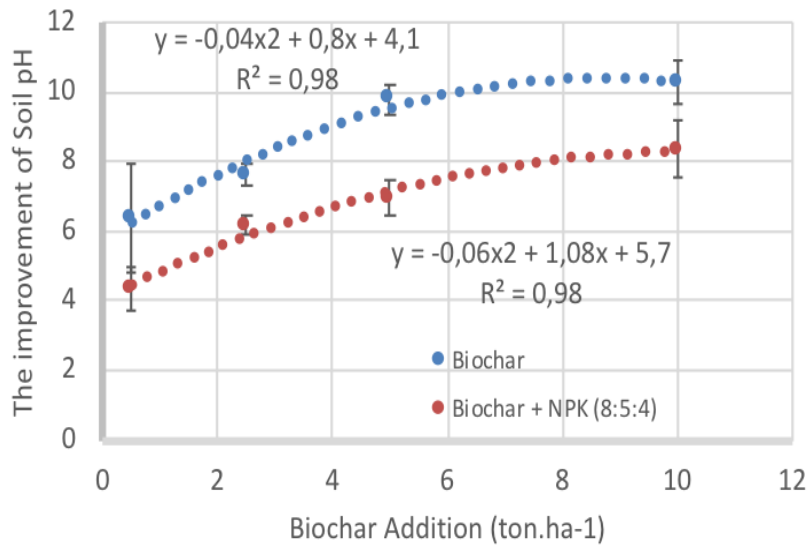

Figure 4. The difference in Ultisols's $\mathrm{pH}$ improvement after the addition of biochar with and without NPK enrichment

Table 4. The absorption and efficiency of soybean NPK due to NPK enrichment on biochar

\begin{tabular}{|c|c|c|c|c|c|c|c|c|c|}
\hline \multirow{2}{*}{$\begin{array}{l}\text { Biochar } \\
+ \text { NPK }\end{array}$} & \multirow{2}{*}{$\begin{array}{c}\text { Dose } \\
\text { (ton ha-1) }\end{array}$} & \multicolumn{3}{|c|}{ Absorption (\%) } & \multicolumn{3}{|c|}{ Efficiency } & \multirow{2}{*}{\multicolumn{2}{|c|}{$\begin{array}{l}\text { Efficiency } \\
\text { Dry Weight }\end{array}$}} \\
\hline & & $\mathbf{N}$ & $\mathbf{P}$ & $K$ & $\mathbf{N}$ & $\mathbf{P}$ & $\mathrm{K}$ & & \\
\hline \multirow{4}{*}{ Biochar with NPK } & 0.5 & 2.84 & 0.069 & 2.08 & & & & & \\
\hline & 2.5 & 3.25 & 0.070 & 2.54 & & & & & \\
\hline & 5 & 3.36 & 0.085 & 3.39 & & & & & \\
\hline & 10 & 3.54 & 0.088 & 3.12 & & & & & \\
\hline \multirow{4}{*}{$\begin{array}{l}\text { Rice straw biochar } \\
+ \text { NPK }(8: 5: 4)\end{array}$} & 0.5 & 3.52 & 0.114 & 2.64 & 0.193 & 0.396 & 0.213 & 0.044 & \\
\hline & 2.5 & 3.41 & 0.142 & 2.88 & 0.048 & 0.507 & 0.121 & 0.031 & \\
\hline & 5 & 3.73 & 0.133 & 4.90 & 0.099 & 0.362 & 0.309 & 0.217 & \\
\hline & 10 & 3.87 & 0.103 & 5.31 & 0.086 & 0.142 & 0.412 & 0.272 & 0.13 \\
\hline \multirow{4}{*}{$\begin{array}{lr}\text { Soybean } & \text { straw } \\
\text { biochar + NPK }(8: 5: 4)\end{array}$} & 0.5 & 3.39 & 0.083 & 2.52 & 0.162 & 0.167 & 0.175 & 0.026 & \\
\hline & 2.5 & 3.64 & 0.107 & 3.06 & 0.106 & 0.346 & 0.170 & 0.109 & \\
\hline & 5 & 3.76 & 0.110 & 4.47 & 0.106 & 0.230 & 0.243 & 0.182 & \\
\hline & 10 & 4.10 & 0.079 & 4.88 & 0.137 & -0.117 & 0.361 & 0.268 & 0.15 \\
\hline \multirow{4}{*}{$\begin{array}{l}\text { Wood biochar + } \\
\text { NPK (8:5:4) }\end{array}$} & 0.5 & 3.84 & 0.101 & 2.57 & 0.261 & 0.318 & 0.190 & 0.033 & \\
\hline & 2.5 & 4.12 & 0.124 & 2.80 & 0.212 & 0.436 & 0.095 & 0.050 & \\
\hline & 5 & 4.13 & 0.129 & 4.80 & 0.186 & 0.340 & 0.294 & 0.212 & \\
\hline & 10 & 4.28 & 0.115 & 5.51 & 0.173 & 0.232 & 0.434 & 0.343 & 0.16 \\
\hline $\mathrm{LSD}_{5 \%}$ & & 0.57 & 0.019 & 0.13 & 0.081 & 0.08 & 0.013 & 0.018 & \\
\hline CV (\%) & & 9.33 & 11.11 & 3.73 & 4.960 & 5.05 & 0.770 & 1.120 & \\
\hline
\end{tabular}




\subsection{The efficiency of NPK-enriched biochar in NPK absorption and the dry weight of soybean}

Table 4 shows the effect of a combination of biochar NPK (with and without enrichment) and doses on NPK absorption (columns 3, 4, and 5). The results reveal similar trends: increasing doses are followed by increasing NPK absorption. Interestingly, $\mathrm{N}$ and $\mathrm{K}$ have higher absorption rates than $\mathrm{P}$. Table 4 also shows the effect of a combination of biochar enrichment and doses on the absorption and efficiency of NPK and the dry weight of soybean. The table shows different sources of the biochar effect on the absorption efficiency of $\mathrm{N}$ (column 6), $\mathrm{P}$ (column 7), K (column 8), and the efficiency of the dry weight of soybean (column 9). Wood biochar + NPK (8:5:4) proves more efficient than other biochar sources.

Specifically, the combination effect of wood biochar + NPK (8:5:4) and doses on $\mathrm{N}$ efficiency (column 6) shows that an increased dose is followed by a decreasing $\mathrm{N}$ efficiency. This is also the case with soybean straw biochar + NPK (8:5:4) and rice straw biochar + NPK (8:5:4). Similarly, there is a trend in the combination effect of biochar + NPK (8:5:4) and doses on $P$ efficiency (column 7). However, this contrasts with $K$ efficiency (column 8). Notably, the combination effect of wood biochar + NPK (8:5:4) and doses on dry weight efficiency (column 9) shows that an increased dose is followed by increasing dry weight efficiency.

\section{Discussion}

\subsection{The properties of biochar}

The biochar samples are visually different across the varying raw sources (Table 1 ) and indicate similar data to that of de Figueredo et al. (2017). The sample generated from wood shows a more compact structure (indicating a high C:N level) compared to that generated from rice or soybean straw (indicating a low $\mathrm{C}: \mathrm{N}$ level). The result of employing various sources for biochar production is visually represented in Figure 1. As seen in the figure, biochar from rice straw and soybean straw (right) is crumblier than biochar from wood (bottom left). This is the result of the chemical test on biochar (Table 1), which shows that $\mathrm{C}$ levels in the biochar from wood are much higher than those from rice straw and soybean straw. The case is the same regarding the level of base elements $(\mathrm{K}, \mathrm{Ca}$, and $\mathrm{Na})$ in rice straw and soybean straw, which prove higher than those of the biochar originating from wood. By contrast, Mg tends to be lower. The nutrient level, especially that require by soybean in great amount (N, P, and K) in biochar. Based on standard status (PPT, 1995) it is categorized as having low and very low concentration (poor). This biochar, when applied in farming lands, particularly old ones (commonly characterized by high levels of acidity or low $\mathrm{pH}$ and NPK levels), leads to disadvantageous impacts on plant production (Table 4, column 9).

Table 1 shows the exceedingly large difference between C:N and C:P (600 to 700), which can imply that biochar matter is very stable in nature or soil, and that the soil characteristics drive it to be resistant to decomposition by microbes. The presence of biochar in the soil for long timespans has the benefit of maintaining soil fertility and quality. In regards to the environmental effect, the function of biochar in soil is to slow down the rate of the increasing temperature of the atmosphere by keeping $\mathrm{C}$ intact in soil and preventing it from turning into $\mathrm{CO}_{2}$ to be emitted into the atmosphere. As such, the use of biochar in agriculture is proven to be environmentally free and to comply with sustainable agriculture systems (Whitman, Scholz, \& Lehmann, 2010; Verheijen et al., 2010).

Based on Table 1 and 2, it could be concluded that the utilization of biochar derived from wood, which had high $\mathrm{C}$ or $\mathrm{C}: \mathrm{N}$ levels and was NPK-enriched, could be an alternative technology for land management to maintain high C-organic in the soils of arable lands. The results of this study are consistent with Kizito et al. (2019): enriched biochar has a great influence on improving soil properties (C and nutrients), which ultimately reduces the need for chemical fertilizers.

\subsection{Decomposition and efficiency of NPK-enriched biochar}

An evaluation of the effect of the biochar addition on Ultisols acid soils shows that biochar that has a high C: $N$ is more stable (biochar that comes from wood). Conversely, biochar enriched with NPK nutrients reduces $\mathrm{C}: \mathrm{N}$, therefore increasing the speed of decomposition. This is closely related to microbial activity, in which more microorganisms play a role in decomposing the material (Powlson, Hirsch, \& Brookes, 2001; Mohammadi, Heidari, Khalesro, \& Sohrabi, 2011). Furthermore, in a long-term soil management program, the higher speed of decomposition must be controlled with more frequent provision of organic material because the organic material in the soil will run out faster (Sun et al., 2019).

Figure 2 shows that the addition of biochar to Ultisols (old) soils to approximately $2.5 \%$ reduces the rate of decomposition. Some research, like Wang and Allison (2019), has shown the difficulty of explaining the saturated condition and biochemical processes because they involve a very complex reaction. During the decomposition process, biochar increases the exchangeable or available bases so it tends to increase soil $\mathrm{pH}$ (decreasing acidity). Therefore, it is very effective on acid soils such as Ultisols (Figure 4). Increasing soil $\mathrm{pH}$ and the availability of bases due to the addition of biochar shows potential in increasing soil productivity, especially in acid soils.

Table 4 shows that increasing the dose of biochar NPK enrichment is followed by an increase in soybean NPK uptake. This is because the enrichment of NPK in biochar increases the availability of NPK in the soil. Based on the data, the highest increase in plant nutrient uptake occurs in $P$, compared to $\mathrm{N}$ and $\mathrm{K}$. This is thought to be closely related to the improvement of acidic soil pH. The increase in NPK uptake by these plants further increases the efficiency of NPK uptake of soybean plants and the efficiency of soybean dry weight.

The highest efficiency of $\mathrm{N}$ absorption occurs on wood biochar (21\%), followed by soybean straw biochar and rice biochar. The highest $\mathrm{P}$ and $\mathrm{K}$ absorption is on rice straw biochar (35\% and $26 \%$, respectively), followed by wood and soybean biochar. The highest soybean dry weight is found on wood biochar (16\%), followed by soybean straw and rice straw. The research findings suggest that the use of woodbased biochar with high amounts of $\mathrm{C}$ or $\mathrm{C}: \mathrm{N}$ and NPK 
enrichment can serve as an alternative in land management to retain high amounts of C-organic in land-use intensification.

As indicated earlier, biochar enrichment to generate NPK (8:5:4) biochar causes the stability of the soil to decline and accelerated decomposition. Nevertheless, NPK absorption by soybean planted in Ultisols is very beneficial. In general, the absorption increases when combining an increased dose and NPK-enriched biochar. Increased soybean NPK absorption not only results from increased biochar dose but also occurs due to NPK enrichment. The maximum soybean nutrient absorption of $\mathrm{P}$ in rice biochar (8:5:4) occurs in 2.5 tons ha- ${ }^{-1}$. This increase in soybean NPK absorption means greater efficiency.

The efficiency estimations were calculated based on comparing soybean NPK absorption in biochar with NPK (8:5:4) enrichment to biochar with no NPK enrichment. The results indicate a consistent pattern in efficiency across different doses and sources. In terms of the nutrients, it is clear that $\mathrm{P}$ is the most dominant $150.7 \%$ with the addition of rice straw biochar 8:5:4 given at 2.5 tons ha-1), followed by $\mathrm{K}$ (43.4\% with the addition of wood biochar 8:5:4 given at 10 tons $\left.\mathrm{ha}^{-1}\right)$, and $\mathrm{N}(26.1 \%$ with the addition of wood biochar $8: 5: 4$ given at 0.5 tons ha $^{-1}$ ). In terms of the NPK status of the soil, the efficiency correlates with the status: there is high efficiency when there is low status.

The improved efficiency of NPK absorption due to NPKenriched biochar also bears impact on the increase in soybean dry weight efficiency. The highest efficiency of soybean dry weight evidentially increases in wood biochar by an average of $16 \%$, followed by soybean straw (15\%) and rice (13\%). In contrast, in terms of the biochar dose, the highest efficiency adds 10 tons ha-1 of wood biochar. The increase in soybean dry weight efficiency is related (correlation coefficient) to the absorption of NPK, typically with $\mathrm{K}$ and $\mathrm{N}$ marked at $0.96^{* *}$ and $0.94^{* *}$ respectively, and $\mathrm{P}$ marked at $0.74^{* *}$.

\section{Conclusion}

Biochar enrichment with NPK has proven influential on Ultisols in declining the stability and escalating the decomposition rate. The stability of NPK-enriched biochar (8:5:4) originating from wood is higher than that originating from rice straw and soybean. NPK-enriched biochar has the potential to improve the efficiency of NPK absorption and soybeans' dry weight. The efficiency of soybeans' dry weight on NPK-enriched biochar treatment is closely correlated with the absorption of $\mathrm{K}$ and $\mathrm{N}$, followed by raw material.

\section{Acknowledgments}

We would like to express our gratitude to Najmi Muhammad and Amanah Fitria for kindly assisting in the completion of the present study. This study denotes part of the applied research supported by the Directorate of Research and Community Service of the Indonesian Ministry of Research, Technology, and Higher Education.

\section{Declaration of Competing Interest}

The authors declare no competing financial or personal interests that may appear and influence the work reported in this paper.

\section{References}

Abel, S., Peters, A., Trinks, S., Schonsky, H., Faklam, M., \& Wessolek, G. (2013). Impact of biochar and hydrochar addition on water retention and water repellency of sandy soil. Geoderma, 202-203, 183-191.

Bachmann, H. J., Bucheli, T. D., Dieguez-Alonso, A., Fabbri, D., Knicker, H., Schmidt, H. P., ... et al. (2016). Toward the standardization of biochar analysis: The COST action TD1107 interlaboratory comparison. Journal of Agricultural and Food Chemistry, 64(2), 513-527. https://doi.org/10.1021/acs.jafc.5b05055

Dariah, A., \& Nurida, N. L. (2012). Pemanfaatan biochar untuk meningkatkan produktivitas lahan kering beriklim kering. Buana Sains, 12(1), 33-38.

de Figueredo, N. A., da Costa, L. M., Melo, L. C. A., Siebeneichlerd, E. A., \& Tronto., J. (2017). Characterization of biochars from different sources and evaluation of release of nutrients and contaminants. Revista Ciência Agronômica, 48(3), 395-403.

Herath, H. M. S. K., Camps-Arbestain, M., Hedley, M. J., Kirschbaun, M. U. F., Wang, T., \& van Hale, R. (2013). Experimental evidence for sequestering $C$ with biochar by avoidance of $\mathrm{CO} 2$ emissions from original feedstock and protection of native soil organic matter. Bioenergy, $7(3), 512-526$.

Kizito, S., Luo, H., Lu, J., Bah, H., Dong, R., \& Wu, S. (2019). Role of nutrient-enriched biochar as a soil amendment during maize growth: exploring practical alternatives to recycle agricultural residuals and to reduce chemical fertilizer demand. Sustainability, 11(3211), 1-22.

Lehmann, J. (2007). Bio-energy in the black. Frontiers in Ecology and the Environment, 5(7), 381-387.

Lehmann, J., \& Joseph, S. (2009). Biochar: environmental management. USA: Earthscan.

Levine, J. (2010). Focused biochar report: assessment of biochar's benefits for the United States of America. Colorado, USA: Centennial Printing.

Manshuri, A. G. (2012). Optimasi pemupukan NPK pada kedelai untuk mempertahankan kesuburan tanah dan hasil tinggi di lahan sawah. Iptek Tanaman Pangan, 7(1), 38-46.

McLaughlin, H., Anderson, P., Shields, F., \& Reed, T. B. (2009). All biochars are not created equal, and how to tell them apart. In North American Biochar Conference (pp. 138). Boulder, Colorado, US.

McLaughlin, H., Shields, F., Jagiello, J., \& Tiele, G. (2012). Analytical options for biochar Adsorption and surface area. In US Biochar Conference 2012 (pp. 1-19). Retrieved from https://www.particletesting.com/wpcontent/uploads/2018/07/PTA-Analytical-Options-forBiochar-Adsorption-and-Surface-Area.pdf

Mohammadi, K., Heidari, G., Khalesro, S., \& Sohrabi, Y. (2011). Soil management, microorganisms, and organic matter interactions: a review. African Journal of Biotechnology, 10(86), 19840-19849.

Mukherjee, A., \& Zimmerman, A. R. (2013). Organic carbon and nutrient release from a range of laboratoryproduced biochars and biochar-soil mixtures. Geoderma, 193-194, 122-130. 
https://doi.org/10.1016/j.geoderma.2012.10.002

Powlson, D. S., Hirsch, P. R., \& Brookes, P. (2001). The role of soil microorganisms in soil organic matter conservation in the tropics. Nutrient Cycling in Agroecosystems, 61(1), 41-51. https://doi.org/10.1023/A:1013338028454

PPT. (1995). Petunjuk teknis evaluasi kesuburan tanah. Laporan Teknis No.14. Versi 1,0.1. REP II Project. Bogor, Indonesia: CSAR.

Sanderman, J., Creamer, C., Baisden, W. T., Farrell, M., \& Fallon., S. (2017). Greater soil carbon stocks and faster turnover rates with increasing agricultural productivity. Soil, 3, 1-16. https://doi.org/10.5194/soil-3-1-2017

Schahczenski, J. (2010). Biochar and sustainable agriculture. (H. Michels, Ed.). ATTRA. Retrieved from www.attra.ncat.org/attra-pub/biochar.html

Sohi, S., Lopez-Capel, E., Krull, E., \& Bol, R. (2009). Biochar, climate change and soil: A review to guide future research (CSIRO Land). CSIRO. Retrieved from http://www.feasta.org/wpcontent/uploads/2009/03/csiro-biochar-climatechange-and-soil-report-feb-20091.pdf

Steinbeiss, S., Gleixner, G., \& Antonietti, M. (2009). Effect of biochar amendment on soil carbon balance and soil microbial activity. Soil Biology and Biochemistry Biochemistry, 41(6), 1301-1310. https://doi.org/10.1016/j.soilbio.2009.03.016

Sun, Z., Liu, S., Zhang, T., Zhao, X., Chen, S., \& Wang, Q. (2019). Priming of soil organic carbon decomposition induced by exogenous organic carbon input: a meta-analysis. Plant and Soil, 443, 463-471. https://doi.org/10.1007/s11104-019-04240-5
Verheijen, F., Jeffery, S., Bastos, A. C., van der Velde, M., \& Diafas, I. (2010). Biochar application to soils: A critical scientific review of effects on soil properties, processes, and functions. Italy: Office for the Official Publications of the European Communities.

Wang, B., \& Allison, S. D. (2019). Emergent properties of organic matter decomposition by soil enzymes. Soil Biology and Biochemistry, 136, 107522. https://doi.org/10.1016/j.soilbio.2019.107522

Wang, J., Xiong, Z., \& Kuzyakov, Y. (2015). Biochar stability in soil: meta-analysis of decomposition and priming effects. Bioenergy, 8(3), 512-523.

Whitman, T., Scholz, S. M., \& Lehmann, J. (2010). Biochar projects for mitigating climate change: an investigation of critical methodology issues for carbon accounting. Carbon Management, 1(1), 89-107.

Winarso, S., Hermiyanto, B., Mandala, M., Sulistiyowati, H., \& Ilmiawan, N. M. (2017). Improvement of soil properties by addition of biochar as enriched fertilizer for growth promoting of soybean plant. Journal of Tropical Soils, 25(2).

Yadav, R. K., Yadav, M. R., Kumar, R., Parihar, C. M., Yadav, N., Bajiya, R., ... Yadav, B. (2017). Role of biochar in mitigation of climate change through carbon sequestration. International Journal of Current Microbiology and Applied Sciences, 6(4), 859-866.

Zheng, R., Chen, Z., Cai, C., X. Wang, \, Huang, Y., Xiao, B., \& Sun, G. (2013). Effect of biochars from rice husk, bran, and straw on heavy metal uptake by pot-grown wheat seedling in a historically contaminated soil. Bio Resources, 8(4), 5965-5982. 